\title{
Between Local Patronage Relationships and Securitization: \\ The Conflict Context in the Bekaa Region
}

Conflict Analysis Report, January 2015

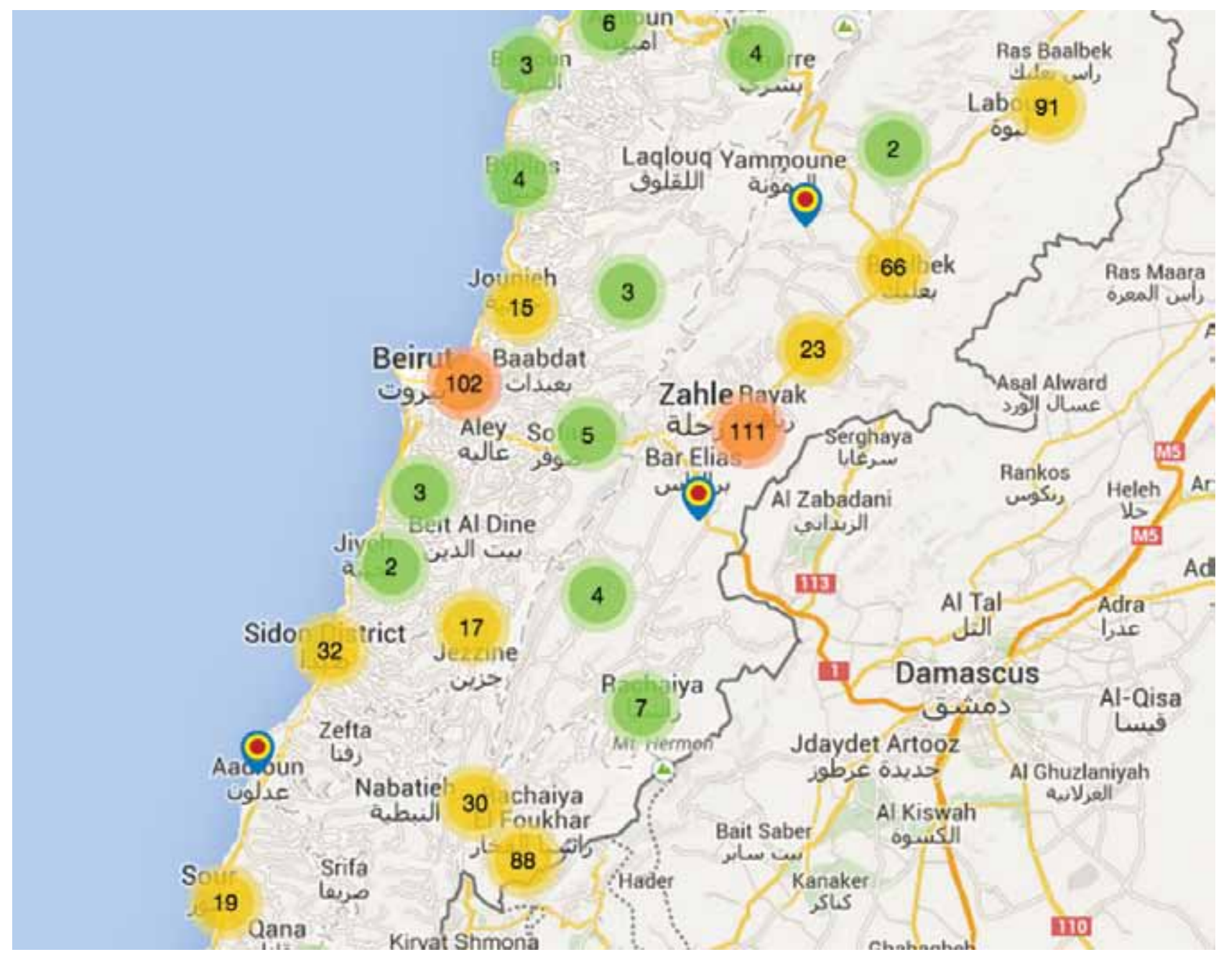

Conflict Mapping \& Analysis map, Civil Society Knowledge Centre, cskc.daleel-madani.org/cma

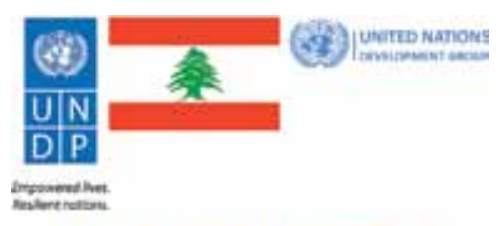

LEBANON RECOVERY FUND
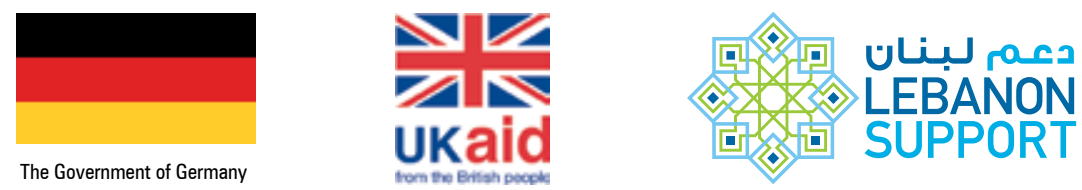


\section{Report written by Muzna al-Masri \\ Published by Lebanon Support, in partnership with UNDP, January 2015.}

Lebanon Support would like to thank the team working on the Conflict Mapping \& Analysis project for its efforts and dedication:

Léa Yammine (Content \& Communication Manager), Désirée Rizk (Documentation Officer), Hiam Fakih (Research Assistant), Marianna al-Tabbaa (Research Assistant), Manon Glaser (Research Assistant), Mohammad Jbara (Research Assistant), Julia Wysocka (Research Assistant), Pasquale Porciello (Research Assistant), and Elia El Khazen (Research Assistant).

Lebanon Support dedicates this project and publication to the memory of Bassem Chit.

The views expressed in this publication are solely those of the author(s), and do not necessarily reflect the views of Lebanon Support, nor UNDP, nor its partners.

Lebanon Support (c) 2015 all rights reserved. 
Between Local Patronage Relationships and Securitization:

The Conflict Context in the Bekaa Region

Conflict Analysis Report, January 2015 



\title{
CONFLICT MAPPING \& ANALYSIS PROJECT
}

\author{
A Project by Lebanon Support \\ Supported by UNDP
}

\section{Preface}

The risk for actors in Lebanon of unintentionally exacerbating or being negatively affected by conflict is high, due in part to the variety and the complexity of existing and potential conflicts. Causes of conflict range from structural sources linked to the Israel-Lebanon border conflict and the political standoff due to the termination but not the resolution of the bloody civil war, to the stressful social, political and economic impacts of more than 1.5 million people who have fled to Lebanon from the crisis in Syria. This added socioeconomic pressure has revealed a deeper layer of preexisting structural causes, including weak-state institutions and systems, which have in turn, triggered collective actions such as demonstrations and roadblocks.

It is therefore fundamental for any actor working in Lebanon, from government entities to local NGOs, from humanitarian agencies to development partners, to be properly informed of this context, of conflict trends, and dynamics all over the country. This is particularly the case for organizations responding to the consequences of the Syrian crisis in Lebanon, which need to be conflict-sensitive in their interventions if they do not want to contribute to generating new tensions.

While many organizations are collecting data and publishing reports on tensions, risks of conflicts, or security-related developments, these publications tend to be either limited to one particular type of conflict (tackling for example the tensions between the host communities and the Syrian de facto refugee, the clashes in Tripoli, etc.), or one particular geographic location (in the area where such organizations are implementing their programs). Moreover, existing reports and analysis on conflict are generally one-off exercises, and many remain confidential and for internal use only.

In order to fill this information gap, the United Nations Development Programme (UNDP*), as the lead agency on Social Stability in the response to the Syrian crisis, partnered with Lebanon Support, the leading Lebanese NGO on information sharing, research, mapping

* This initiative is implemented through UNDP Peace Building in Lebanon Project. 
and analysis, provides up-to-date, publicly available information on the wide range of conflict issues affecting Lebanon. This conflict mapping and analysis project was launched in June 2014, with support from the UK and Germany (through the Lebanon Recovery Fund). This project, implemented and developed by Lebanon Support, provides a sophisticated, impartial and pragmatic understanding of the inner workings of tracked conflicts: the specific underlying social fabric, the political minefields, as well as the opportunities for positive action. It has two main components:

1. The conflict map tracks incidents (whether between armed groups, government entities, or on individual levels), protests and mobilization, as well as conflicts at the borders, and maps their location throughout Lebanon. It is continuously updated by a team of experts and researchers cross-checking and triangulating data. The incidents are categorized following a conflict typology (classification), which, together with a number of additional filters (for example the categories of incidents), enables users to access the information most relevant to their respective programs/research.

2. The conflict analysis adds a more qualitative element to the project, analyzing conflict dynamics and particular trends, with reports produced every four months focusing each time on a specific geographic location or conflict type. The first report, released today, focuses on conflict trends, issues, actors and dynamics in the Bekaa, in the aftermath of the armed clashes in Arsal since early August.

While conflict modeling still cannot be considered an accurate science, this project relies on a multi-disciplinary team that goes beyond mere quantifiable factors and statistical data (which have proved over the last decades - and other experiences in other contexts - their limits when it comes to identifying for instance, a potential tipping point into violence). It provides, based on extensive ethnographic fieldwork, an in-depth look into the social, economic and political dynamics in Lebanon today, which may account as factors creating the conditions for conflict.

Over time, this information and analysis system allows one to define trends in tensions and conflicts. It also allows one to understand underlying causes of tensions and conflicts so as to better tailor interventions and enhance coordination between humanitarian and development actors in Lebanon. And ultimately, it constitutes a tool for reflection for policy makers, researchers, and other experts to better inform the process of policy making and public action in Lebanon. This is an ambitious and exciting project, the first of its kind in Lebanon. UNDP and Lebanon Support hope that our partnership will provide quality information and analysis to all humanitarian, development and stabilization partners in the country, and will contribute to increasing the impact of the work of international, national and local partners in Lebanon.

Beirut, the $16^{\text {th }}$ of December 2014

$\begin{array}{ll}\text { LEBANON SUPPORT } & \text { UNDP } \\ \text { Marie-Noëlle Abi Yaghi } & \text { Luca Renda } \\ \text { President/Head of Research } & \text { Country Director }\end{array}$




\section{TABLE OF CONTENTS}

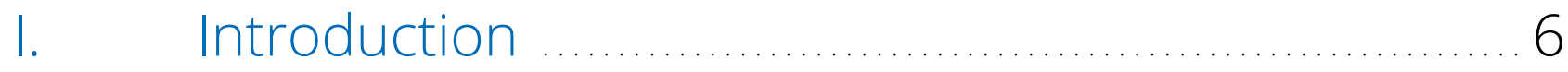

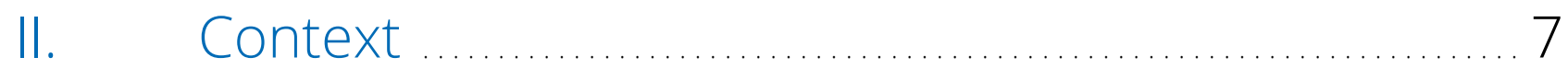

III. Conflict Issues ....................................... 11

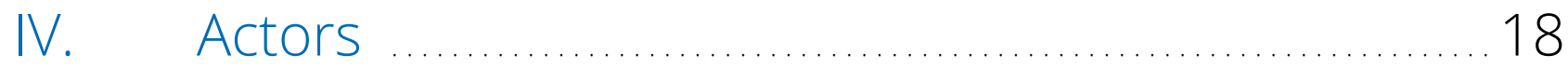

V. Dynamics ................................................. 23

VI. Recommended conflict mitigation strategies ........25

VII. $\quad$ Case Study .............................................. 26 
$\mathrm{Nb}$ of mapped incidents,

in Lebanon

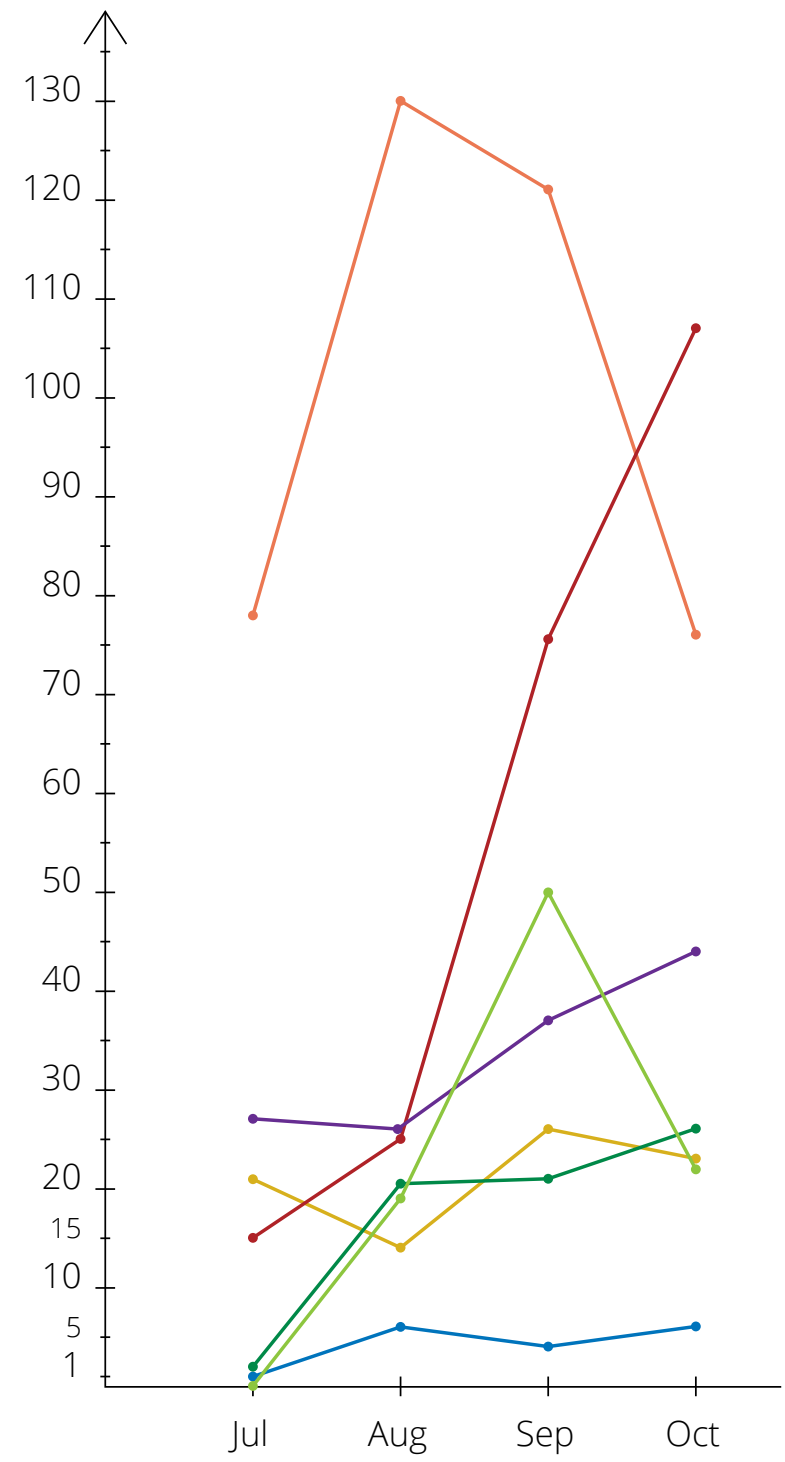

Boundary conflicts (Lebanon/Syria) Total: 84

Boundary conflicts

(Lebanon/Israeli Occupation) Total: 405

Power and governance conflicts Total: 222

Conflicts of socio-economic development Total: 17

Conflicts of social discrimination Total: 69

Individual acts of violence Total: 134

Policy conflicts

Total: 91

FIGURE 1:

Overview of reported and mapped conflicts in Lebanon, between July and October 2014.

This classification typology was created based on an analysis of existing incidents. It attempts to provide users with a different method of reading the results of the interactive map, available online on the Civil Society Knowledge Centre (CSKC) ${ }^{1}$.

\footnotetext{
1 Lebanon Support would like to note that data and statistics read without an analytical level may be misleading, especially since no remarkable trend in data can be noticed over the span of four months. This applies to all graphs and visualizations included in this report. Figures 1, 2, 4 and 6 were produced by Lebanon support based on the the Conflict mapping available on http://cskc.daleel-madani.org/cma and are not the author's.
} 
$\mathrm{Nb}$ of mapped incidents,

in Bekaa governorate

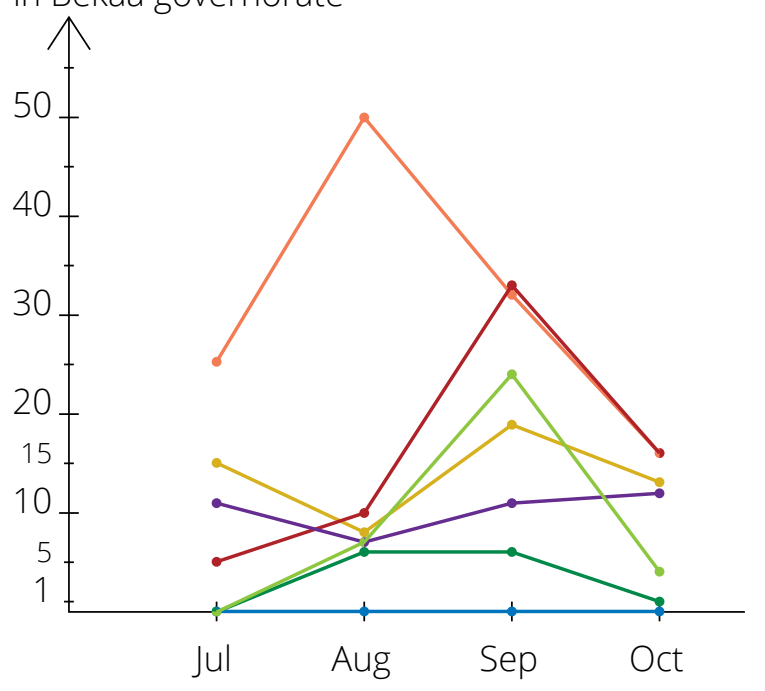

Boundary conflicts (Lebanon/Syria)

Total: 55

Boundary conflicts (Lebanon/Israeli Occupation) Total: 123

Power and governance conflicts

Total: 64

Conflicts of socio-economic development Total: 0

Conflicts of social discrimination

Total: 13

Individual acts of violence

Total: 41

Policy conflicts

Total: 35

FIGURE 2:

Overview of reported and mapped conflicts in the Beqaa Governorate, between July and October 2014. 


\section{Introduction}

This report provides an analytical summary of the conflict context in the Bekaa region of Lebanon, with a focus on the relationships between the Syrian de facto refugees and the Lebanese host communities in the Baalbeck-Hermel area. It is based on a socio-political qualitative assessment and a conflict analysis that are primarily based on experiences and perspectives of key informants, ${ }^{2}$ as well as Lebanese and Syrian residents of the Bekaa. Unless otherwise noted, information in this report is based on these interviews. The report is intended as a quick reading of the field at a set point in time, and does not provide a political or military analysis nor predicts future scenarios, and should not be assumed to reflect what is happening at the national level.

The fieldwork was implemented between September $10^{\text {th }}$ and October $11^{\text {th }} 2014$. As a qualitative research, it included over 20 one-to-one interviews with Syrian de facto refugees, members of the Lebanese host communities, religious and intellectual figures, NGO representatives, and members of the local authorities. The report is divided into two sections. The first section provides an analytical summary of the conflict context in the Bekaa generally, using a variety of analysis tools that cover three broad dimensions of conflict as suggested by Gattiker, ${ }^{3}$ namely, actors, issues, and dynamics (see figure 3). In addition, the first section provides a modified political, economic, social and technological (PEST) analysis of the context in the Bekaa, as well as recommendations for a conflict prevention and peace building strategy. The second section provides a case study that exemplifies how these conflict issues and dynamics are experienced by individual Syrian de facto refugees and members of the Lebanese host communities. The case study also aims to demonstrate the connections between different issues and their impact on various social groups.

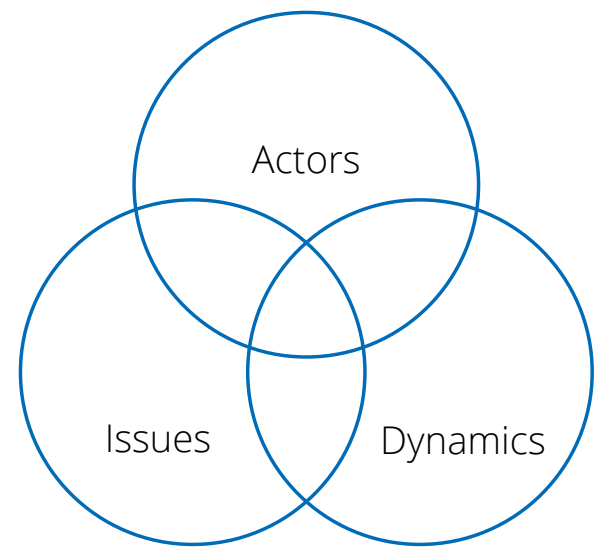

FIGURE 3:

Conflict Dimensions

\footnotetext{
2 Key informants were selected to include individuals with knowledge that covers the region or the subregion broadly, and to reflect a variety of expertise, political leanings, and sectarian belonging. Existing social network of researchers was used in addition to recommendations by civil society activists based in the Bekaa. These included at least one of each of the following categories: civil society activists, relief workers, journalists, religious personnel and mayors. While such figures are traditional conflict analysis tools that are widely used, they do not necessarily reflect Lebanon Support's perspective. Lebanon Support adopts a broad multidisciplinary approach to conflict analysis. This also applies to figures 3 and 7.

3 See Regula Gattiker, Mapping of Tools and Guidelines for ConflictAnalysis in the ContextofConflict Transformation, Swisspeace, 2007.
} 


\section{Context}

\section{A. DEMOGRAPHY:}

According to the UNHCR, ${ }^{4}$ as of October $1^{\text {st }} 2014$, the Bekaa is host to 404,806 registered Syrian de facto refugee, a number that has been in rapid increase up till the end of September $\left(418,303 \text { registered Syrian de facto refugees on September } 26^{\text {th }}\right)^{5}$ when the numbers started decreasing slightly, possibly as a result of the clashes in Arsal in August 2014. The number of Syrian de facto refugees is almost equivalent to the total number of residents in the Bekaa region before the refugee crisis, which was at 489,865 in $2007 .{ }^{6}$

\section{B. POLITICAL AND RELIGIOUS COMPOSITION:}

Administratively, the Bekaa is divided into five Cazas that reflect to a great extent the political and sectarian character of the sub-regions, as detailed in the table below. In addition to these five sub-regions, two other areas can be seen as forming together separate geographic entities with common security concerns.

- Border areas: This first area includes villages on the Lebanese-Syrian border, particularly those of the Baalbeck-Hermel area starting from Brital all the way to Hermel, because of their susceptibility to attacks or infiltrations by militant groups from Syria, mainly where geographic conditions and military control of bordering Syrian areas allow those. This proximity to the border, not only creates a condition of heightened insecurity, but also increases local tensions and mistrust of the refugee population.

- Beirut-Baalbek highway: The second area includes villages along the Beirut-Baalbek highway through which traffic to most areas of the northern Bekaa is bound to pass, and on which kidnappings and riots are more likely to happen.

On the surface, it might appear that the Bekaa is clearly divided between a predominantly Shiite northern Bekaa in support of March $8^{\text {th }}$, and a predominantly Sunni southern Bekaa in support of March $14^{\text {th }} \cdot{ }^{7}$ In reality, there is significant religious diversity in both areas with

\footnotetext{
4 UNHCR, Syria Regional Refugee Response: Inter-agency Information Sharing Portal, available at: http://data.unhcr.org/syrianrefugees/settlement.php?id=201\&country=122\&region=90 [last accessed 05/10/2014]

5 Interviews with Arsal residents and media reports at the time indicate a significant refugee influx in the wake of the fighting in the Qalamoun/Qusair in Syria in November 2013

6 Central Administration of Statistics, Living Conditions Survey 2007, 2008, p. 24, available at: http://www.cas.gov.lb/images/PDFs/Living\%20conditions\%20survey\%202007.zip [last accessed 14/11/2014].

7 Both coalitions solidified in the two months following the assassination of Prime Minister Rafic Hariri in 2005, and continue today to define the political divide at the national level. The March $8^{\text {th }}$ political camp lead by Hezbollah took a strong pro-resistance to Israel position and allied itself with the regimes of Iran and Syria. It contested claims that the Syrian regime was after the assassination and saw in it support for the resistance against Israel, and supports the regime through the current crisis in Syria. Its members refused calls for disarmament of Hezbollah's resistance asserting that Israel continues to be a threat to Lebanon and that some Lebanese land continues to be occupied. Its members include another Shiite political group, the Amal movement, the Christian Free Patriotic Movement, as well as some of the communist and nationalist parties. The March $14^{\text {th }}$ political alliance is headed by Future Movement, and is composed of political groups that accused the Syrian regime of being behind the assassination of Hariri and protested its presence in Lebanon. Regionally, it allies itself with Saudi Arabia. According to members of the alliance, military resistance to Israel was not a priority since the liberation of the south of Lebanon in the year 2000, and thus calls for disarming Hezbollah were made. Besides mostly Sunni Future Movement, members of the alliance included Christian political groups, the Lebanese Forces and the Kataeb.
} 
several religiously mixed villages. Compared to other areas of Lebanon, the Bekaa also has always enjoyed a long history of coexistence as it has not witnessed major displacement, battles or atrocities during the 1975-1990 Lebanese civil war, and thus there is little if any resurgence of long brewing political feuds in the current crisis. In addition, the historical allegiances of some groups, particularly the Sunnis in their belonging to Arab Nationalist groups including the Baath party, and the Shiite to leftist political parties, counters simplistic division of the two areas between an anti-Syrian March $14^{\text {th }}$ South Bekaa and a pro-Syrian March $8^{\text {th }}$ North Bekaa respectively. As we will describe in the section on actors, families and tribes also still play an important political and social role, which at times is more significant than that of political parties.

\section{Religious and Political Composition by Caza}

\begin{tabular}{|c|c|c|}
\hline Sub-region & Religious composition & Political context and allegiance \\
\hline Hermel & Predominantly Shiite & \multirow[b]{2}{*}{$\begin{array}{l}\text { The March } 8^{\text {th }} \text { movement won all } \\
\text { the seats of the area in the } 2009 \\
\text { parliamentary elections, the latest } \\
\text { parliamentary elections to take place } \\
\text { in Lebanon to date. In addition to a } \\
\text { Hezbollah majority, parliamentarians } \\
\text { include representatives of the } \\
\text { Amal Movement, the Baath party, } \\
\text { Almarada, and the Syrian Social } \\
\text { Nationalist Party }\end{array}$} \\
\hline Baalbeck & $\begin{array}{l}\text { Predominantly Shiite with some } \\
\text { Sunni, Christian Maronite and } \\
\text { Greek Orthodox, as well as } \\
\text { several mixed villages }\end{array}$ & \\
\hline Zahle & $\begin{array}{l}\text { Religiously mixed, including: } \\
\text { - Catholics (the majority of Zahle's } \\
\text { residents); } \\
\text { - Maronites; } \\
\text { - Greek Orthodox (particularly in } \\
\text { the eastern villages of Zahle like } \\
\text { Kfar Zabad, Quossaya, Deir Al- } \\
\text { Ghazal, etc.); } \\
\text { - Sunnis, particularly in the } \\
\text { regions of Kabb Elias and Bar } \\
\text { Elias, the two largest villages in } \\
\text { the Caza and those hosting the } \\
\text { largest number of Syrian de facto } \\
\text { refugees; } \\
\text { - Shiites. }\end{array}$ & \multirow{3}{*}{$\begin{array}{l}\text { The March } 14^{\text {th }} \text { movement won all } \\
\text { the seats of the area in the } 2009 \\
\text { parliamentary elections. Key political } \\
\text { groups include: } \\
\text { - Lebanese Forces, particularly } \\
\text { among the Maronite and some of the } \\
\text { Catholic residents; } \\
\text { - Free Patriotic Movement, } \\
\text { particularly in Greek-Orthodox } \\
\text { villages; } \\
\text { - Future movement in Sunni villages, } \\
\text { although traditionally the Sunnis of } \\
\text { the area had pro-Syrian politics; } \\
\text { - Hezbollah and Amal Movement in } \\
\text { Shiite villages; } \\
\text { - The Progressive Socialist Party } \\
\text { (PSP)/Jumblatt supporters in Druze } \\
\text { villages of Rashaya; } \\
\text { - Traditional feudal families, } \\
\text { particularly the Skaff family whose } \\
\text { popularity and political influence is in } \\
\text { decline; } \\
\text { - There is no significant presence of } \\
\text { nationalist or leftist political parties. }\end{array}$} \\
\hline West Bekaa & $\begin{array}{l}\text { Predominantly Sunni with some } \\
\text { Christian and Shiite villages }\end{array}$ & \\
\hline Rashaya & Predominantly Druze & \\
\hline
\end{tabular}




\section{SECURITY:}

Making your way through the planes of the Bekaa area, the landscape appears dotted with recent conflict incidents and signs of the turbulent context. The signs of an agitated conflict situation are hard to escape. On any given day you go to the Bekaa, you are bound to be told that a kidnapping took place just yesterday on one road or that there were clashes through the night up behind that hill. Lebanese army soldiers are in helmets in well-fortified checkpoints and the streets are almost empty during night-time. Since the beginning of the political crisis in Syria, the region has suffered from the spillover of the conflict given the geographic proximity to the Syrian border. This includes the shelling from Syria into border areas, border clashes, and most recently, the clashes in Arsal in the summer of $2014 .^{8}$

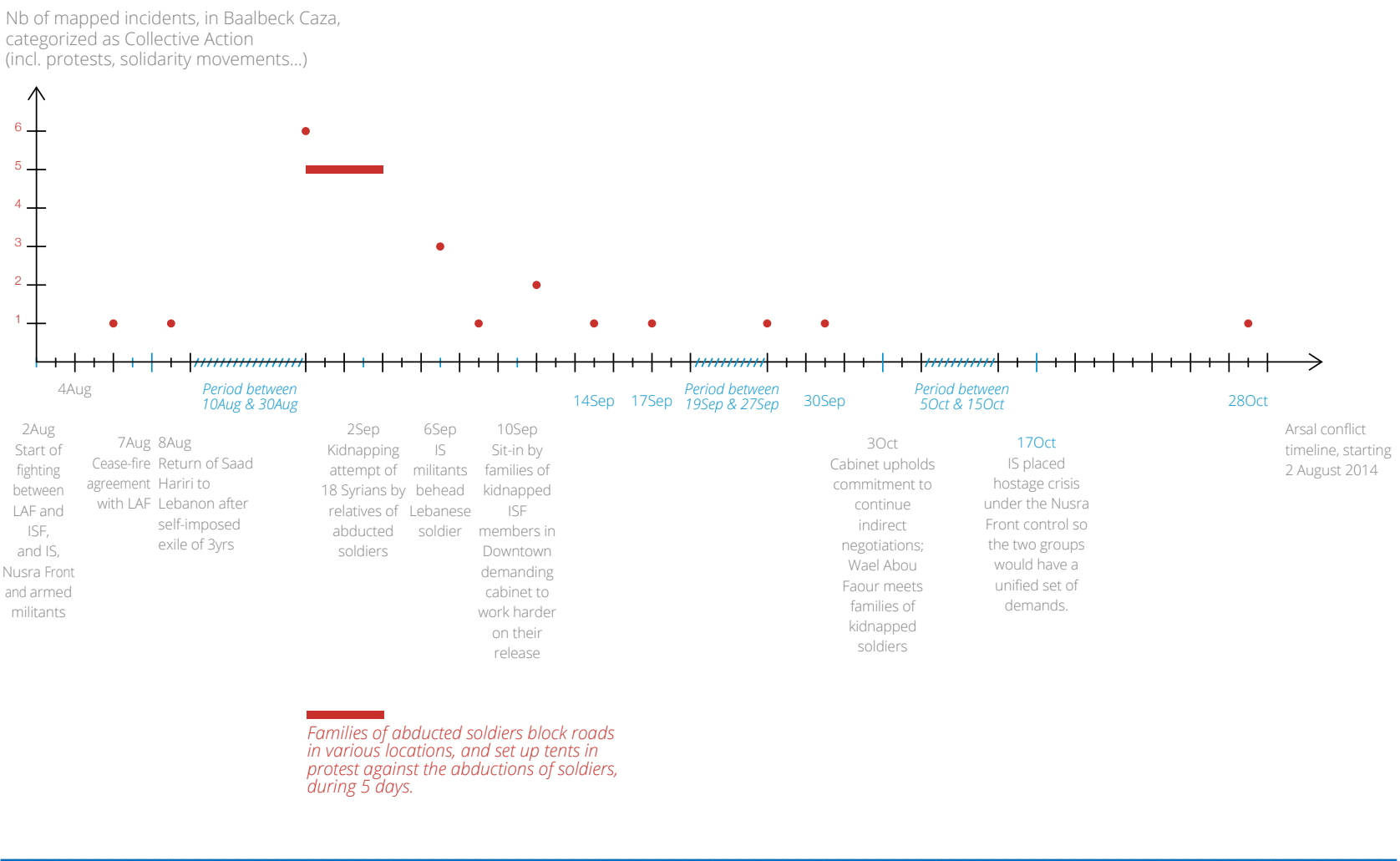

FIGURE 4:

Timeline of collective action incidents in Baalbeck Caza between August and October 2014.

\section{ECONOMY:}

According to interviewees, the mostly rural population of the Bekaa relies on three means of livelihood. The first is the cultivation of fruits and vegetables, and the agro-food industries like dairy products, canned and frozen vegetables, potato chips and wine. The second is the employment in the public sector, particularly in the Lebanese Armed Forces (LAF) and the Internal Security Forces (ISF). The third is the cultivation and smuggling of marijuana as well as other smuggling across the Syrian border. "Smuggling" within this third sector needs to be understood as a continuation of the long existing permeability of the Lebanese-Syrian

8 See the "Arsal Conflict Timeline" here: http://cskc.daleel-madani.org/arsal-timeline 
borders that allowed the residents of the Bekaa to benefit from the cheaper prices in Syria and escape Lebanese customs. Other smaller sectors exist, including the tourism sector and the small industries of ceramics and building products. ${ }^{9}$

With the influx of Syrian de facto refugees, the population of the already marginalized and relatively poor areas has almost doubled in the past three years. ${ }^{10}$ At the same time, the Bekaa faced economic hardship as a result of the closure of its export routes via Syria, a fragile security situation that has almost completely destroyed the tourism sector, and has prompted the transformation of smuggling routes - once open to small scale smugglers - into militarized routes. Those routes possibly still function as arms and personnel smuggling routes, and are under a renewed control that may have marginalized smaller scale smugglers. ${ }^{11}$

\footnotetext{
9 Economic activity here is described based on information given by key informants as the author has no knowledge of existing research that gives a description of the sources of income locally, including clandestine smuggling activities. That smuggling and cultivation of marijuana existing in Lebanon is a long acknowledged fact, yet their share of the local economy as well as the impact of the Syrian crisis on profits is disputed. See for example local Al-Akhbar's claim in September this year that Marijuana farmers are struggling (Louai Falha, "Lebanon: Marijuana farmers in the Bekaa struggling to survive as profits decline", Al Akhbar, English, September 13 ${ }^{\text {th }}$ 2014, available at: http://english.al-akhbar.com/node/21517) versus the Guardian's claim less than a month later that the trade is struggling ("Lebanon cannabis trade thrives in shadow of Isis war", The Guardian, October 10 2014 http://www.theguardian.com/world/video/2014/oct/10/lebanon-cannabis-isiswar-video) - [both last accessed November 25 2014$]$.

10 In 2008, although the Bekaa had average prevalence of overall poverty (29\%), it had higher than average prevalence of extreme poverty (10.8\%) particularly in the areas of Baalbeck and Hermel. Source: Heba ElLaithy, Khalid Abu-Ismail and Kamal Hamdan, Poverty, Growth, and Income Distribution in Lebanon, UNDP/ International Poverty Centre, 2008, p. 110.

11 The intersection between the economy of arms trade and marijuana production on the one hand, and the interests and positions of local political players, including Islamic militant groups, Hezbollah, and local families and clans on the other hand, as well as the nature of the subject makes the collection of reliable information on the subject quite difficult and well beyond the scope of this report.
} 


\section{Conflict Issues}

The identification of structural and proximate causes of conflict in Lebanon has been a long and contentious issue of debate by social and political scientists, as well as peacebuilding practitioners. ${ }^{12}$ The majority of the conflict issues identified in this report are local manifestations of national level conflicts and their causes. Out of this broad literature, the report highlights fifteen issues, some embedded in long enduring structural causes, others becoming manifest only in the past couple of years or months and are results of proximate causes and events.

The literature generally agrees that the long enduring clientelistic sectarian-based powersharing political system is at the root of many of Lebanon's remerging conflicts. Also long entrenched are the centralized development policies that favor the city of Beirut and the marginalization of the rural areas not least the Bekaa region. In the past decade, Lebanon has witnessed a sharp political divide between two political camps that have solidified in March 2005 into the previously described March $8^{\text {th }}$ and March $14^{\text {th }}$ camps. The position in relation to the events of Syria coincided with these divisions, with the March $14^{\text {th }}$ coalition providing support for the Syrian opposition, and March $8^{\text {th }}$ standing in support of the Syrian regime. A long brewing Sunni-Shiite sectarian divisive discourse has underlined this division, and grew with the increased militarization of the Syrian conflict and Hezbollah's involvement in it.

At a more proximate level, the "spillover" of the Syrian crisis in Lebanon has been felt in various arenas, including the social, economic, and humanitarian levels, not only the political one, increasing the internal Lebanese divisions and straining its limited resources. The socio-economic impact of the crisis triggered various conflict issues, including competition over economic resources including jobs and aid. The political and security reverberations have meant repeated security infringements on Lebanese border areas, growth of Islamist militant groups, an increase in the proliferation of arms, and more recently, the exacerbation of security situation in the Bekaa generally, and in Arsal in particular.

Figure 5 provides a summary of the issues that are of particular relevance to the Bekaa region. ${ }^{13}$ While some of these issues are at once causes of conflict and triggers caused by other issues, this report only elaborates on the intermediate level issues, which are seen to be within the scope of intervention of aid and peace-building organizations.

\footnotetext{
12 See for example, Oussama Safa, Lebanon Conflict Analysis, ForumZFD, 2013; Elizabeth Picard and Alexander Ramsbotham, Reconciliation, Reform and Resilience: Positive Peace for Lebanon, Conciliation Resources, 2012 ; Martin Kraft, Muzna Al-Masri, Heiko Wimmen, and Natascha Zupan, Walking the Line: Strategic Approaches to Peacebuilding in Lebanon, Working Group on Development and Peace (FriEnt), 2012.

13 While such figures are traditional conflict analysis tools that are widely used, they do not necessarily reflect Lebanon Support's perspective. Lebanon Support adopts a broad multi-disciplinary approach to conflict analysis. This also applies to figures 3 and 7.
} 


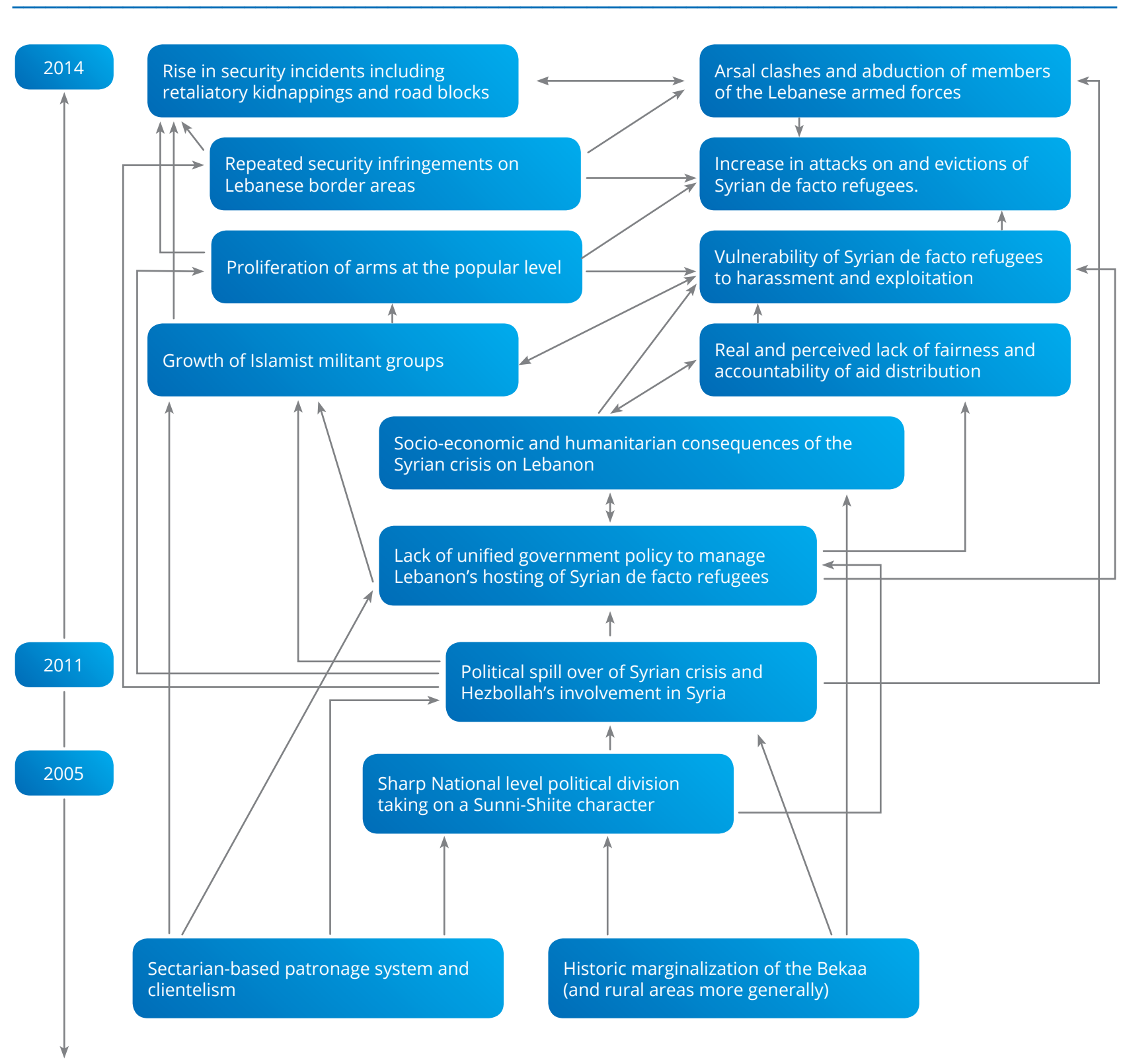

FIGURE 5:

Conflict Issues in the Bekaa Region

\section{A. LACK OF UNIFIED GOVERNMENT POLICY TO MANAGE LEBANON'S HOSTING OF SYRIAN DE FACTO REFUGEES AND SECURITIZATION OF THE SYRIAN CRISIS: ${ }^{14}$}

The key political figures in the country are divided in their position vis-à-vis the Syrian crisis and the management of the Syrian de facto refugee influx and their needs. Since the beginning of the crisis, the Lebanese borders have generally remained open, but policy fluctuated and depended to a large extent on the political leanings of the Lebanese official making policy-related decisions. In practice, this has meant that Syrian de facto refugees have been subject to the impromptu decisions of landowners, municipalities, and

\footnotetext{
14 For a discussion about the government policy on Syrian de facto refugees see Karim El Mufti, "Official response to the Syrian refugee crisis in Lebanon: the disastrous policy of no-policy", Civil Society Knowledge Center, Lebanon Support, January $10^{\text {th }}$ 2014, available at: http://cskc.daleel-madani.org/paper/official-response-syrian-refugee-crisislebanon-disastrous-policy-no-policy [last accessed November 20th 2014 ]
} 
aid organizations, as well as the fickle government policy. The Arsal crisis has brought back a discussion of hosting Syrian de facto refugees to the forefront, particularly in efforts to limit the number of Syrian de facto refugees in Arsal, as well as the illegal entry and exit from Syria. While no camps for Syrian de facto refugees exist, informal tented settlements abound, ${ }^{15}$ particularly in the Bekaa and Arsal since the Qalamoun clashes in Syria in autumn 2013. According to the interviewees from the Ballbeck-Hermel area, proposals for a Lebanese hosting policy have included among others:

1. The establishment of refugee camps in the no man's land between the Lebanese and Syrian borders.

2. The establishment of a few large Lebanese government-managed camps in areas where they do not pose a risk of becoming hubs for political mobilization.

3. Improved management of existing settlements, through appointment of Lebanese camp coordinators.

Political disagreement, security considerations, and concerns over long-term implications of establishing refugee camps prevented a decision on any of the above, although in parallel, many decisions made have had significant impact on the lives of the Syrian de facto refugees. These included delaying and limiting school registration for Syrian de facto refugee children and the waiver of a Syrian's right to refugee status if he or she leaves Lebanon and decides to come back. ${ }^{16}$ In October, measures were introduced that have drastically limited the entry of Syrian de facto refugees to Lebanon, bare "humanitarian cases" upon a government decision that, up till the writing of this report, had not been made publicly clear. ${ }^{17}$

In parallel, both discourse and policy have moved towards securitization of the Syrian de facto refugee issue. Politicians and the media have long propagated the framing of Syrian de facto refugees as a security threat. ${ }^{18}$ With reports that some members of the militant groups have emerged from the settlements of Syrian de facto refugees, ${ }^{19}$ this discourse has gained further vigor. Yet this process of securitization is not a mere discursive one and has been backed by government policy.

In September 2013 for example, the Ministry of Interior advised municipalities to take a number of security measures, many of which reflect on the Syrian de facto refugees, including the employment of local police, registration of all Syrian de facto refugees and monitoring aid distribution, as well as the purchase of weapons when necessary. ${ }^{20}$

\footnotetext{
15 A total of 1,224 informal settlements as of 31 May 2014, around 70\% of their residents being in the Bekaa. See Mona Fawaz, Nizar Saghiyeh and Karim Nammour, Housing Land and Property Issues in Lebanon: Implications of the Syrian Refugee Crisis, UNHCR and UN-Habitat, 2014.
}

16 See Press release of Minister of Interior, May 31 st 2014, available at http://www.interior.gov.lb/AdsDetails. aspx?ida=111 accessed 29/10/2014 [last accessed November 20th 2014].

17 See the Daily Star's interview with the Minister of Social Affairs on October 20 2014 on the implemented measures: Elise Knutsen, "Lebanon Drastically Limits Syrian Refugee Entry", The Daily Star, English, October 20th 2014 , available at:

http://www.dailystar.com.lb/News/Lebanon-News/2014/Oct-20/274632-lebanon-drastically-limits-syrianrefugee-entry.ashx\#axzz3KHUaa9rc [last accessed November 20 2014$]$.

18 See Bassem Chit, Mohamad Ali Nayel, "Understanding racism against Syrian refugees in Lebanon", Lebanon Support, October 28 $8^{\text {th }}$ 2013, available at: http://cskc.daleel-madani.org/paper/understanding-racism-againstsyrian-refugees-lebanon [last accessed November $20^{\text {th }} 2014$ ].

19 See as an example Assafir's reporting from Arsal on September 26 th 2014 , "النازحين ماذا عن .." Assafir, Arabic, September 26"th 2014, available at: http://assafir.com/Article/2/374693/AuthorArticle [last accessed November 20th 2014].

20 See "Memorandum of Ministry of Interior" dated 11 September 2013 available on 
According to one civil society activist in the West Bekaa area, those security officers, whose main job has been to impose restrictions on the movement of Syrian de facto refugees, often do not have the requisite training and skills. Since the Arsal crisis, municipalities in the Bekaa have also been advised by the Baalbeck-Hermel governor to survey all resident Syrian de facto refugees within their areas and perform security checks on the places of residence of Syrian de facto refugees (See figure 8). According to the Syrian de facto refugees interviewed, recent security measures by the LAF have further exacerbated the vulnerable situation of Syrian de facto refugees, presenting them as a security threat to the host communities without providing adequate protection when they are mistreated. According to some Syrian de facto refugees, army raids on houses and informal settlements have been random and often included ill-treatment, for example, according to one Syrian de facto refugee in the West Bekaa: "We were humiliated and slapped in front of our children. They dragged me on the floor and my girls started crying". This, according to the same interviewee, was in response to them not having renewed their residency permits in Lebanon, and happened to other Syrian de facto refugees living in the same settlement, none of whom will report it. Security concerns have also been used to justify evictions of informal settlements by the LAF, ${ }^{21}$ municipalities, land owners or vigilante groups (see case study for examples).

\section{B. SOCIO-ECONOMIC AND HUMANITARIAN CONSEQUENCES OF THE SYRIAN CRISIS IN LEBANON:}

Given the long social and economic historical relationships between the people of Lebanon and Syria and the border they share, the socio-economic hardship that Lebanon is experiencing is more a result of the Syrian crisis generally than it is the impact of hosting Syrian de facto refugees. A September 2013 World Bank report detailed the "large, negative and growing" social and economic impact of the crisis on Lebanon: cutting GDP growth, increasing the number of Lebanese living in poverty and decreasing the government revenue. ${ }^{22}$ While the report attributes such losses to the insecurity in Syria, the deterioration in the security situation in Lebanon in 2014 further exacerbates it. The report argues that such negative impact is felt in the tourism sector and in the trade sector due to the decrease of Syria's role as a trading partner, and given that most of Lebanon's export routes go through Syria. Due to the large influx of Syrian de facto refugees, Lebanon's infrastructure will be strained, including water supply, sanitation, solid waste management, electricity, and the transport network. The human development and social impact element includes an increase in demand on health, education and social safety nets, and last but not least, is the impact of the crisis on the already strained labour market, and reports anticipate this to result in further unemployment and informality.

With the security concerns overshadowing other issues at the time of fieldwork and the impact of the crisis mainly felt on the macro level and thus seemingly elusive to

http://www.interior.gov.Ib/AdsDetails.aspx?ida=68 [last accessed October 29th 2014 ].

21 While the aforementioned UNHCR and UN-Habitat's 2014 (ibid) report indicated some evictions of Syrian de facto refugees by the LAF from settlements due their proximity to a LAF base or other security concerns, aid workers interviewed in the Bekaa have indicated that these evictions have increased after the Arsal clashes. It should be noted that one of the camps we visited during the course of this assessment in October 2014 received, according to the camp coordinator, an eviction notice from the LAF one week after our visit due to its proximity to a LAF base.

22 World Bank, Lebanon: Economic and Social Impact Assessment of the Syrian Conflict, Washington DC: World Bank, 2013, pp. 1-5, available at: http://documents.worldbank.org/curated/en/2013/09/18292074/lebanoneconomic-social-impact-assessment-syrian-conflict [last accessed December $16^{\text {th }} 2014$ ]. 
the interviewees at the local level, what was relayed to us by the interviewees on this issue was minimal, and mainly focused on the infrastructure, the difficulty in exporting agricultural products and marketing them internally, and the labor market. One municipal board member reported the increased pressure on the village's already derelict water tank, describing efforts to secure funding form international organizations to build a new tank for the benefit of both the Syrian de facto refugees and the members of the community.

The impact of the labor market changes was on semi-skilled labor, with the influx of the Syrian de facto refugees competing with local small-scale contractors, particularly in the construction industry like plumbers and painters. Possibly the most affected by the influx of Syrian de facto refugees were the Syrian workers who worked in Lebanon before the crisis, with competition over low-waged jobs, not traditionally taken by the Lebanese, further lowering wages of Syrians. One Lebanese farmer from the Bekaa, who for years has worked with seasonal agricultural workers from Syria, describes the impact of the crisis on his work relations. Today he explains that families who used to come to work on his farm seasonally are living permanently in Lebanon, and he is renting them land to live on. The day of work on his farm has increased in length by one or two hours for the same pay, and he can now be choosy in selecting workers that perform better because of abundance of labour. The main difficulty from his perspective was marketing his products within Lebanon, given the difficulties of the security situation in Lebanon more generally and the road closures.

\section{REAL AND PERCEIVED LACK OF FAIRNESS AND ACCOUNTABILITY OF AID DISTRIBUTION:}

Syria is the biggest humanitarian crisis in the world today, and understandably, the management of support and aid to those affected by it has been a challenging task. From the perspective of the Syrian de facto refugees, aid policy appears ambiguous and unpredictable. The Syrian de facto refugees we spoke to often did not know where most of the aid they are receiving is coming from, did not understand changes in aid policy over time, nor were they clear as to where to find information on issues related to aid, their livelihood, and the education of their children. When describing education opportunities for her children, one Syrian mother in the Hermel region was not aware of the difference between public schooling, private schooling, and NGO-lead informal education activities that might be available to her children, and was as concerned with transportation to school as much as she was with access to the school itself. In an informal interview with one municipal official, we discussed opportunities to get her son to school. He expressed not knowing what options were available beyond the public schools, which at the time were still awaiting a ministerial decision on taking in Syrian students.

In addition, accusations of corruption and mismanagement, typically fuelled by rumors, were readily made by the interviewees, often as blanket accusations against all the aid organizations. According to one aid worker, the rush to deliver support for the influx of Syrian de facto refugees in Arsal in late 2013 for example, caused mismanagement problems, and although readily and transparently dealt with, it has caused a surge of rumors and accusations beyond the specific incident. Many aid organizations recognize the problems of mismanagement, and some have clear accountability policies in place. Nevertheless, the aid workers we interviewed expressed the difficulty of ensuring accountability given the huge scope and rapid pace of the operation. As 
a senior staff member of one international organizations indicated, if mismanagement or fraud is identified, there are a few measures that can be taken beyond dismissing staff committing fraudulent behavior. These same staff members are often employed by other aid organizations that might be reluctant to implement the proper reference checks. Transparency in dealing with fraud allegations, as examples have shown, further exacerbates the spread of rumors and mistrust of the aid industry among the Syrian de facto refugees, instead of nurturing a culture of accountability.

In contrast, the often-politicized aid arriving from the Gulf countries, or through religious institutions, is presented to Syrian de facto refugees through more personal and direct channels. This form of aid, according to the interviewees form Arsal for example, has gained further popularity with the decline of aid from the UN agencies. According to the same source, such provision often comes with demands for political loyalty, which - if refused means that aid is discontinued.

\section{VULNERABILITY OF SYRIAN DE FACTO REFUGEES TO HARASSMENT AND EXPLOITATION:}

The interviews we conducted clearly indicate that the Syrian de facto refugees in Lebanon are vulnerable to both, government and politically sanctioned exploitation and discrimination, as well as arbitrary acts of violence by community members (see case study for examples). All such acts have increased since the events of Arsal, as indicated in the below case study. ${ }^{23}$ Direct attacks on informal settlements, that we have documented, were undertaken by vigilante groups or young men without political backing. In fact, where these incidents were reported, local authorities, political parties, as well as community members, have condemned such acts and sought to provide protection to Syrian de facto refugees by means available to them. These attacks have been paralleled by security measures taken by the LAF, including raids and checkpoints, which - as mentioned earlier - have often involved ill-treatment of Syrian de facto refugees. The proliferation of arms at the local level has further weakened the position of the Syrian de facto refugees, particularly as almost all the cases reported to us have indicated that attack perpetrators were armed. This process is sanctioned by several political parties, as well as the Ministry of Interior at the municipal level, as noted previously.

\footnotetext{
23 See also, Human Rights Watch, Lebanon: Rising Violence Targets Syrian Refugees: Authorities Should Protect Syrians, Prosecute Attackers, September 30th 2014, available at: http://www.hrw.org/news/2014/09/30/lebanonrising-violence-targets-syrian-refugees [last accessed December 16 $6^{\text {th }} 2014$ ].
} 


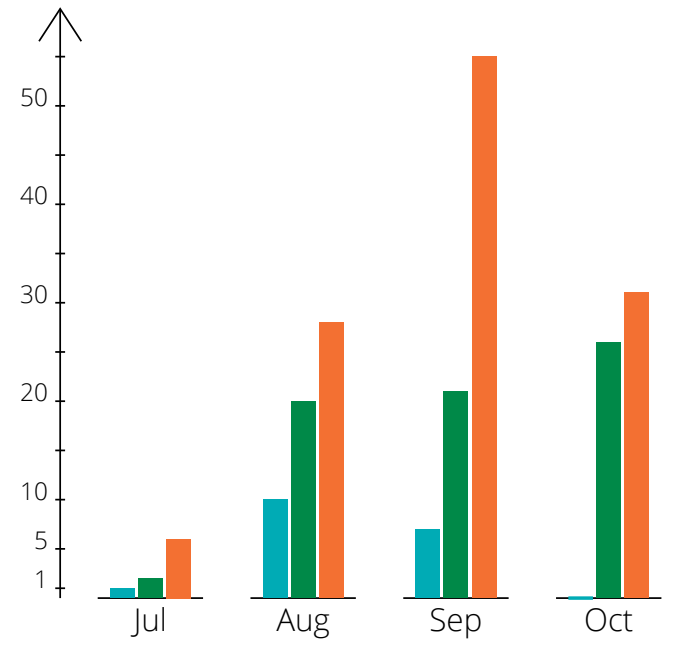

- Incidents classified as conflicts of social discrimination

- Incidents categorized as curfew

- Incidents categorized as collective action (incl. protests, solidarity movements...)

* Incidents' categories describe the nature of the mapped incident, whereas the classification provides an analytical reading of the incident and which kind of conflict it falls under. The classifications were developed based on an analysis of existing incidents.

FIGURE 6:

Ratio of curfew and collective action incidents and conflicts of social discrimination mapped between July and October 2014.

This vulnerability is forcing the Syrian de facto refugees to seek membership in local patronage networks for protection, including that provided by landowners on whose land informal settlements are constructed, employers, and local political actors. While such patronage networks provide some guarantee of safety for the Syrian de facto refugees, they are not in themselves free of exploitation. In one informal settlement we visited in the West Bekaa, the Shawish (camp coordinator) had long established ties with the Syrian de facto refugees he hosted on his land. Most of them had worked with him before the crisis as seasonal workers, and he now provides them with seasonal employment on his land, as well as arranging for them to work with other farmers. While he defended them against attacks and made sure they were paid by other employers, he also paid them less per working day than he did before the crisis, and if he found the politics of any of his workers not to his liking, he readily dismissed them from the settlement. 


\section{Actors}

While most actors in the Bekaa region have national, and some even regional presence, the overview below seeks to (1) sketch the positions and alliances particular to the Bekaa, and (2) highlight local level actors who have significant impact within the region or governorate. The description below is based predominantly on the input from key informants as well as interviewees from among the Lebanese and Syrian de facto refugee community. While it is informed by media reporting, it is an analytical summary of the various subjective opinions and assessments of the key informants. The order by which the actors appear in the below list is random.

It is worthy to note, before we move on to the description of actors, that beyond the duality of the March $8^{\text {th }}$ vs. March $14^{\text {th }}$ coalitions described earlier, the Sunni-Shiite divide, or that of the Syrian regime and its opposition, the intra-sectarian dynamics, particularly among the Sunni communities in the coming period, merit as much attention as the intersectarian conflicts. According to several interviewees, the allegiances and sentiments of the Sunni communities today, as noted in the below account of the first three actors, waver between the various political actors who present themselves as the voice of the Sunni communities. These allegiances and sentiments of members of these communities depend on their members' attitude towards the violence practiced by the militant jihadi groups, the perceived "threat" of Hezbollah as a Shiite armed group, and the importance of sectarian belonging as compared to national Lebanese or Arab belonging. (See figure 7 for a mapping of the actors and the relationship between them).

1. Militant jihadi groups: Include AI-Nusra Front (hereafter NF), ${ }^{24}$ the Islamic State in Iraq and Syria/the Levant (ISIL or ISIS), ${ }^{25}$ and Abdullah Azzam Brigades (AAB). ${ }^{26}$ These groups hold significant military and economic power, mainly through funding and support from individuals and groups in the Gulf countries. In their involvement in Arsal in August 2014, these groups are primarily seeking access to shelter and amenities come wintertime, particularly after the Qalamoun clashes last year in Syria, which have largely closed off their paths into Syrian territory. The current clash with Hezbollah is primarily in relation to the party's involvement in Syria in support of the Syrian regime, with an underlying sectarian Sunni-Shiite element. All have been also involved in other areas of Lebanon, including bombings in Beirut's southern suburbs and fighting and mobilization in the north of Lebanon. In terms of the relationships between these groups, clashes between the ISIL and the NF took place earlier this year, although both groups appear to have joined forces at the Lebanese border. The NF is also described by the interviewees as less brutal than ISIL as it is more reluctant to easily commit executions. ${ }^{27}$ In relation to Syrian de facto refugees,

\footnotetext{
${ }^{24}$ For further information, see: "Jahbat al-Nusra", Mapping Militant Organizations, Stanford University, available at: http://web.stanford.edu/group/mappingmilitants/cgi-bin/groups/view/493 [last accessed October $28^{\text {th }}$ 2014]; "Spot-On Actors: al-Nusra Front ", Lebanon Support, available at: http://cskc.daleel-madani.org/party/ al-nusra-front [last accessed December $\left.12^{\text {th }} 2014\right]$.

${ }^{25}$ For further information see: "Islamic State in Iraq and Syria", Mapping Militant Organizations, Stanford University, available at: http://web.stanford.edu/group/mappingmilitants/cgi-bin/groups/view/1 [last accessed October 28th 2014]; "Spot-On Actors: Islamic State (IS)/ Daech", Lebanon Support, available at: http:// cskc.daleel-madani.org/party/islamic-state-daech [last accessed December $12^{\text {th }} 2014$ ].

26 The above brief introduction of key actors from among Islamic Jihad groups is by no means exhaustive nor reflecting their regional and global allegiances, and only aims to highlight key players in the Bekaa region at the time of writing this report.

27 This was most recently evident when the NF went back on its threat to execute captive soldiers in response to the LAF operation in Tripoli.
} 
the groups have posited themselves as speakers on behalf of the Syrian de facto refugees, repeatedly demanding their protection by Lebanese authorities. With the scarcity of other voices speaking on behalf of the Syrian de facto refugees, such calls might be aiming to secure political supportfrom among the Syrian de facto refugees but could also be partially motivated by some of the fighters having family from among the Syrian de facto refugee population.

2. Sunni Islamic groups: Include the Muslim Scholars and Jamaa Islamia. Both groups present a Sunni Islamic agenda that is non-militant, and because of that, they have gained wider popular acceptance than the Jihadi groups. The newly established Muslim Scholars includes around 500 religious scholars brought together by a democratic structure with frequent change in leadership. ${ }^{28}$ Although within their ranks the scholars have a wide variety of religious traditions, the political tone in the past year has been of a clear Sunni identity, support for the Syrian revolution, and antagonism towards Hezbollah. These groups are at the moment relying on philanthropic efforts to maintain a support base, with most of their political discourse being a mediating one between the militant groups and the Lebanese state $^{29}$. According to several interviewees, they have come to be perceived in the wake of the Arsal clashes as a voice that, unlike the temperate discourse of Future Movement, adequately represents the Sunni sentiments without the violent activities of militant groups.

3. Future Movement and the March $14^{\text {th }}$ alliance: The growing role of Sunni Islamic and militant groups has pushed the Future Movement (FM) into a more moderate position in the conflict with Hezbollah as compared to 2005, before the jihadi militant groups had their present day military and political power. In its public position, the FM still provides public support to the LAF and the state institutions. It continues to enjoy a large support base in the Sunni communities since it won, along with other March $14^{\text {th }}$ forces, all the seats of Zahle and the West Bekaa. The FM also won the leadership of many municipalities in the 2010 municipal elections, and has the institutional and electoral infrastructure to sustain it at the local level. According to interviewees that are members of the Sunni communities, it has not performed up to their aspirations as a representative of the Sunni sect vis-à-vis the increasingly powerful Shiite Hezbollah. This, according to key informants, has led to some vacillation among members of the community between the FM and groups like the Muslim Scholars. For other members of the March $14^{\text {th }}$ alliance, particularly the predominantly Christian parties of the Lebanese Forces and the Phalanges Party, the political position appears as complex. In Christian border villages like Ras Baalbeck and Qaa, some members of the Lebanese Forces and the Phalanges Party, and despite their political opposition to Hezbollah at the national level, have not objected to - if they have not provided support to - Hezbollah's fighting against the Islamic militant groups. This is interpreted by some of the interviewees as a disconnect between, on the one hand, the leadership of the two Christian parties which maintain their political opposition to Hezbollah, and on the other hand, their grassroots membership in the Bekaa who are less opposed to Hezbollah because of their geographical proximity to the fighting and to the perceived increased power of the militant jihadi groups. It is, in any case, a matter of concern among members of the Christian communities; the growing power of militant Islamist groups, particularly after the Islamic State's takeover of Mosul in Iraq and the treatment of Christians there.

4. Hezbollah, Amal Movement and other members of the March $8^{\text {th }}$ alliance: The position of Hezbollah in support of the Syrian regime has been clear since the start of the

\footnotetext{
28 According to the Muslim Scholars Facebook page which to date has over 17,000 likes, available at: https://ar-ar.facebook.com/muslim.olama [last accessed November 17th 2014 ].

${ }^{29}$ As evident in their mediation efforts between the Islamic militant groups who had captured the LAF soldiers (see Arsal timeline).
} 
Syrian crisis. ${ }^{30}$ Its involvement in the fighting in Syria is tangible at the community level in the Bekaa with the high death toll that the fighting had entailed from among the Party's supporters. ${ }^{31}$ This human cost appears not to have had a negative impact on Hezbollah's popular support base, particularly with the increasingly anti-Shiite discourse of Islamic militant groups and Hezbollah's apparent military superiority. Despite the continued strong political alliance, relationships between Hezbollah and members of its ally, the Amal Movement, are facing some - largely muted - tensions at the popular level. Among Christian communities in villages close to the Lebanese border, interviewees have conveyed that members of the Free Patriotic Movement (FPM) are playing an instrumental role in supporting Hezbollah's and the LAF military, particularly through local level patrolling and policing. This support is not only a result of the political allegiance between the FPM and Hezbollah, but it is also rooted in the concern among some members of the Christian community in relation to the perceived growing power of the militant Islamic groups.

5. The Lebanese Army: It is today at the forefront of the military action. Since the May 2008 clashes in Beirut, it was presented as biased towards the March $8^{\text {th }}$ camp, and is said to have Hezbollah militants fighting along its side on the ground in the Bekaa today. Nevertheless, it still enjoys a strong popular support base across political divisions as one of the few solid state institutions that are maintaining Lebanon's unity and stability. The fact that a good percentage of the local population in the Bekaa - and the north - has family members in the LAF gives it greater support among members of the Lebanese host communities. Despite the recent defections of some Sunni soldiers to join militant Islamic groups and some rumors of a possible split within its ranks, the LAF appears to continue to enjoy internal cohesion. If the army receives the promised Saudi funding and equipment, this will not only signal the LAF's increased power, but would also be indicative of the political buy-in and support from Saudi Arabia for the LAF's agenda.

6. Communist and nationalist parties and traditional local actors: Historically, the Bekaa's population has been active with numerous political groups, including the Lebanese Communist Party, the Syrian Nationalist Party and the Baath. Local traditional leaders also still enjoy relative power, particularly ex-minister Abdul Rahim Murad, an advocate of Arab nationalism, as well as the Syrian regime today, who has built a constituency through patronage networks and several well-established local institutions not least the Lebanese International University. ${ }^{32}$ Despite the lack of significant political power, members (or exmembers) of these groups play, as individuals, a mediating role at the community level and provide models of political allegiance that break away from predefined sectarian belonging. This includes the anti-sectarian sentiments of some of the Arab nationalist members of the Sunni communities who today align themselves with the March $8^{\text {th }}$ political camp, and the voice of some communists who are critical of Hezbollah's role locally.

7. Families of abducted soldiers: With their primary interest being the release of their abducted family members, the families vary in their political position. Some are standing

\footnotetext{
30 For details on Hezbollah's perspective on the conflict see: International Crisis Group, A Precarious Balancing Act: Lebanon and the Syrian Conflict, Middle East Report N¹32 - 22, November 2012.

31 While Hezbollah has not officially published the death toll from among its fighters, the most accurate assessment of the death toll as of 29/03/2014 appears to be 332 Hezbollah fighters according to blogger Hisham Ashkar:

http://mostlyoff.wordpress.com/2014/03/31/funerals-of-hezbollah-fighters-killed-in-syria/ [last accessed November $17^{\text {th }}$ 2014]. Interviews in the Bekaa region indicate that this number has risen significantly since the clashes in Arsal, particularly fighters who are from the Bekaa region.

32 For more on Murad's biography and political leanings see his interview with Al-Akhbar on 24/03/2012 (in Arabic), http://www.al-akhbar.com/node/58996 accessed 17/11/2014.
} 
strongly with the army while others are calling for the army and the Lebanese government to accept the demands of the ISIL and the NF. Efforts to put pressure on the government to ensure the release of their sons through blockades of the Damascus road and other local roads had some negative impact on the community. Some families have also played a positive and reconciliatory role in affirming cross-sectarian solidarity and through public calls that no retaliatory measures are taken against Syrian de facto refugees ${ }^{33}$.

8. Local families and tribes: Tribal and familial allegiance is possibly stronger in the Bekaa than in any other region of Lebanon, and has been most evident in recent months in the cases of retaliatory kidnappings and road blockings that took place across various regions. The variety in families, their allegiances, and their roles is too broad to outline in this report, though necessary to take into consideration at any local level intervention. Examples of families that have been involved in security incidents in the past few months include the Hujeiri and Fleiti Sunni families of Arsal, the Shiite Al-Masri ${ }^{34}$ and Zaiter ${ }^{35}$, and the Bedouin tribe Arab el-Weiss ${ }^{36}$. Many of the young vigilante groups are emerging from within these families and tribes, and fortunately when identified, easily succumb to family pressure to put a halt to their vigilante activities. In addition, many smuggling and drug trafficking networks, a major source of income in the Bekaa, are dependent on such networks for their operation.

9. Aid community: Seemingly a strong actor with its comparatively massive resources deployed in a stagnant economy, the role it actually plays remains well below its potential. Limited coordination between various actors, perceived mismanagement of resources, and limited conflict sensitivity posit the humanitarian aid community as an actor that enjoys limited trust at the local level. In parallel, aid coming from non-traditional donors, including individual and religious donors from the Gulf, is distributed without proper monitoring and often with strings demanding political loyalty. ${ }^{37}$

10. Syrian de facto refugees: A significant, though passive, stakeholder primarily due to their sheer numbers. They are often used as a bargaining chip among key actors, be it militant groups which posited themselves as the protectors of the Syrian de facto refugees or political groups presenting them as a soon to explode source of danger. Despite a growing number of Syrian led aid and civil society institutions, ${ }^{38}$ there still is little, if any, political or rights based voices that speak and act on behalf of the Syrian de facto refugees in Lebanon.

33 See Yazan al-Saadi, "Protesting, negotiations, and dysfunctional politics: The case of the abducted Lebanese soldiers", Civil Society Knowledge Center, Lebanon Support, December 23rd 2014, available at http://cskc. daleel-madani.org/content/protesting-negotiations-and-dysfunctional-politics-case-abducted-lebanesesoldiers [last accessed January 2nd 2015].

34 Members of which were responsible for one of the kidnappings of individuals from Arsal in September 2014, soon after released after family pressure.

35 Of whom wanted drug dealer Nouh Zaiter hails. Most recently arrested by the Lebanese authorities in Baalbeck on October $11^{\text {th }}$, and escaped with the support of his family on the same day.

36 According to reports of some local NGOs, the tribe is responsible for many disruptions in aid distribution in the west and central Bekaa as its members try to ensure that they receive a share of the distributed aid.

37 See: Dalya Mitri, "Challenges of aid coordination in a complex crisis: An overview of funding policies and conditions regarding aid provision to Syrian refugees in Lebanon", Civil Society Knowledge Center, Lebanon Support, May 23rd, 2014, available at: http://cskc.daleel-madani.org/paper/challenges-aid-coordinationcomplex-crisis [last accessed December 16 $6^{\text {th }} 2014$ ].

38 For examples see Malath al-Zoubi, "Syrian Civil Society Takes Root in Lebanon », The Syrian Observer, August $7^{\text {th }}$, 2013, available at: http://www.damascusbureau.org/?p=5708 [last accessed November 20th 2014]; Elisabeth Longuenesse, 2014, «Plongée dans un camp de réfugiés syriens de la Bekaa: Prendre en charge son destin », Orient XXI, April 7th 2014 available at: http://orientxxi.info/magazine/plongee-dans-un-camp-derefugies,0558 [last accessed November 20th 2014]. 
Syrian de facto refugees are not part of the decision-making process on aid policies, and only have limited, localized and sporadic input in managing informal settlements. If a Syrian de facto refugee today is subject to exploitation or ill-treatment by a member of the public, or a political or governmental authority, he or she has no rights based complaint mechanism. Given this absence of representative voices, which speak on behalf of the Syrian de facto refugees and their rights, and no clear policy by the Lebanese government, the Syrian de facto refugees remain subject to both, exploitation by local patronage networks and mobilization by militant groups.

11. Municipalities: Municipalities do not present a unified actor and their contribution to the conflict dynamics varies depending on the power and political allegiance of their members. In relation to the relationships between the Syrian de facto refugees and the host communities, they seem to play an increasingly important role in the Bekaa region in the past year, particularly in security monitoring as discussed in the section on issues earlier. Municipal members are also playing a mediatory role in conflicts taking place between Syrian de facto refugees and members of their community, and for Syrian de facto refugees, the municipality is often the first point of reference in the community.

12. Camp coordinators (or Shawish): Camp coordinators are either Syrian or Lebanese nationals. Syrian camp coordinators are usually tribal or community leaders who enjoyed social status in their community, and took on organizational or representative duties when in Lebanon. Lebanese camp coordinators are often landowners or employers of agricultural workers who are hosting or managing the work of Syrian agriculture day laborers. Their role often is based on pre-existing relations with Syrian communities. Their role within the conflict context varies, and whereas they play a buffer role between the Syrian residents and the members of the community, they, at times, could economically exploit the Syrian de facto refugees they are hosting or enforce certain political allegiances.

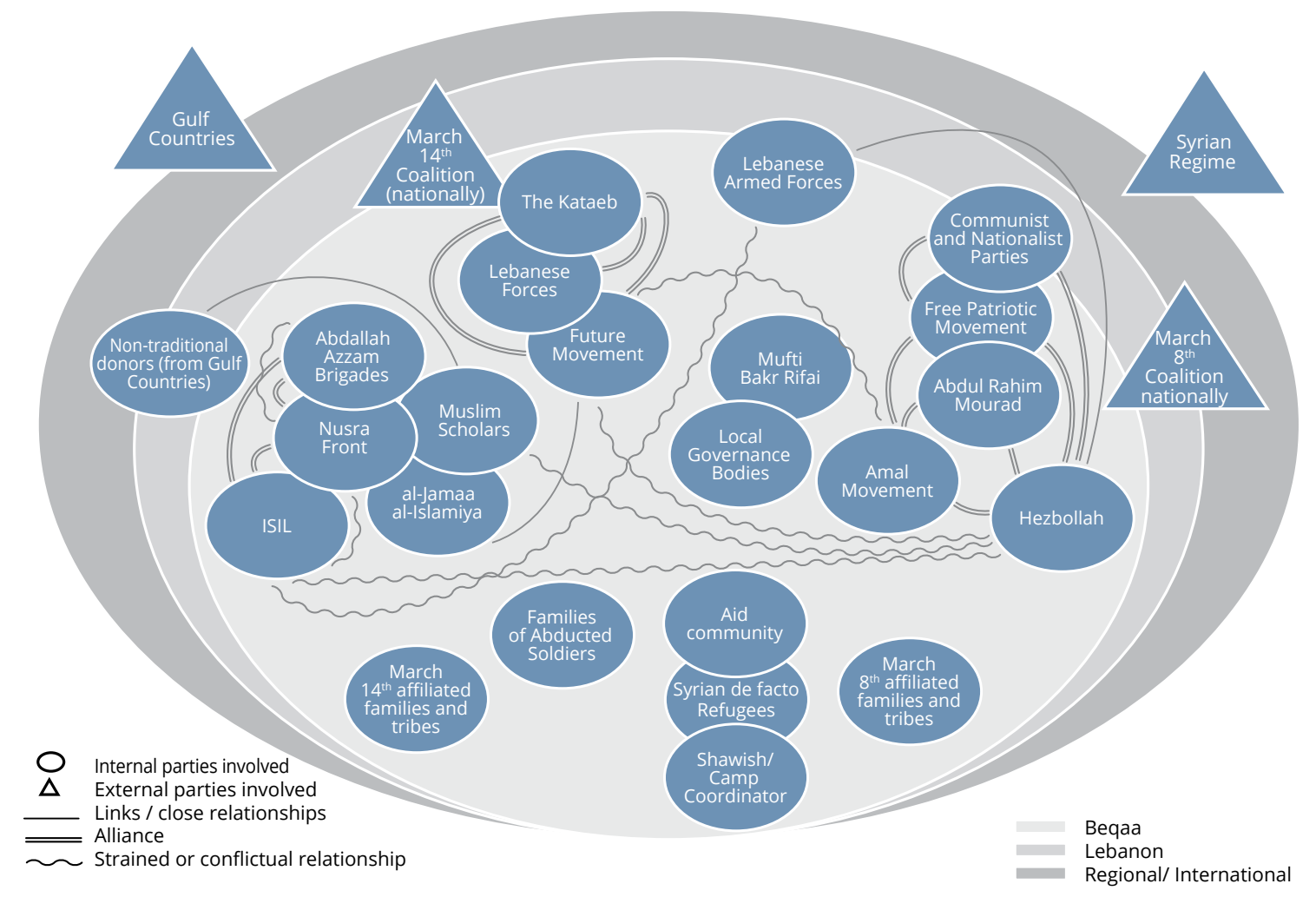

FIGURE 7: 


\section{Dynamics}

\section{DIVIDERS AND CONNECTORS ${ }^{39}$}

Dividers and connectors are elements in a conflict setting which divide people from each other (dividers) and serve as sources of tension, or which connect people and can serve as local capacities for peace (connectors). They are dynamic and change over time, and they do not refer to certain individuals or actors, but to actions or conditions that affect the conflict.

\section{DIVIDERS}

1. Negative media portrayal of Syrian de facto refugees, often as members of militant groups, ordinary criminals and/or impoverished helpless communities. Such portrayal fuels hostile sentiments towards Syrian de facto refugees and exacerbates their harassment and exploitation.

2. Use of excessive and performative force by security agents in their raids on informal settlements of Syrian de facto refugees. This is increasing the feelings of indignation towards the Lebanese authorities and could contribute to greater support for militant groups.

3. A lack of willingness on the part of Syrian de facto refugees to report incidents of harassment that they are facing. This is not only a result of powerlessness and a feeling that such reporting would not improve their situation. The Syrians we spoke to appeared to hold an understanding - and according to one interviewee possibly rooted in their political experiences in Syria - that if such events are happening and in public, then they are bound to be sanctioned by the authorities. This is strengthened by a practice of silence sustained by members of the Lebanese community, who tend to downplay the frequency, and intensity of such incidents.

4. Ambiguity of the source of attack and harassment of Syrian de facto refugees and the lack of accountability for attacks taking place. In particular, some vigilante groups falsely claim that they belong to powerful local actors, including Hezbollah, state security institutions or notable families and tribes. Often the lack of clarity as to which of the security agencies is responsible for a particular operation, as well as security agents dressing in civilian clothing (with only a vest to identify them), further blurs the boundary between state security agencies and non-state actors.

5. By passing Syrian de facto refugees in the process of resolution of conflicts they are party to, or cases of exploitation they are subjected to.

\section{CONNECTORS:}

A long established history of Syrian-Lebanese relationships at the community level, including marriage and business relationships. This is more evident in the Bekaa than

\footnotetext{
39 Developed by the Collaborative for Development Action (CDA) as part of the Do No Harm/Local Capacities for Peace program. For a description see http://www.conflictsensitivity.org/node/103 [last accessed November $\left.17^{\text {th }} 2014\right]$.
} 
win any other area in Lebanon, due to the region's proximity to Syria and the economic ties enjoyed between the two. In cases we have observed, such personal relationships have been used by some Syrian de facto refugees to ensure their protection and/or provide livelihood support.

2. Efforts on the part of some politicians, parliamentarians, and religious figures to diffuse tensions at the local level and to ensure that no political cover is provided to vigilante groups. It is worthy to note the "charter of honor" signed by religious figures, political actors, and members of the Lebanese parliament from the Baalbeck and Hermel area on September $15^{\text {th }} 2014$. The charter denounced violence - particularly retaliatory kidnappings - and declared that those who commit such violence will not be provided with any form of protection from politicians. This in practice meant that Hezbollah and Amal denunciated acts of violence committed by their supporters within the area.

3. Calls for restraint on the part of families of the first two abducted soldiers to be killed by the militant Islamist groups. When he was beheaded, the family of Sgt Ali Sayyed, a Sunni from Akkar, had requested that no retaliatory action be taken against Syrian de facto refugees. In an act of cross-sectarian solidarity, when soldier Abbas Medlej was beheaded soon after, the family of Sayyed, along with key figures from his village, travelled to the Bekaa and paid condolences to the family of the Shiite soldier.

4. Local and traditional forces at the community level continue to hold and exercise measures of control over vigilante groups. Personal and familial ties are observed to be used repeatedly to free kidnapped individuals in short time periods. Family pressure as well as local custom is also evoked to halt attacks on Syrian de facto refugees who are residing on land owned by local members of the community. Members of the municipality as well as political parties locally have also interfered in several cases in defense of Syrian de facto refugees.

5. Despite growing tension, Bekaa residents prioritize local allegiances and security concerns over national level political affiliation. This reduces their susceptibility to national level mobilization. 


\section{Recommended Conflict Mitigation Strategies}

The tense security situation in the Bekaa appears to cast a shadow over most sociopolitical relationships, be it between various Lebanese actors or between Syrian de facto refugees and the Syrian host communities. The major divide is the one between the LAF and the militant Islamic groups overshadowing - though often also inflating - other lines of division. Political allegiances are being questioned and reshaped, and new lines of division are forming in response to the dynamics of the conflict. This tense security situation is fertile ground for exploitation of the most vulnerable groups, most notably the Syrian de facto refugees, and minor conflicts hold the potential for facile escalation if no conscious mitigation efforts are made. The recommendations below focus on strengthening the local networks and infrastructure capable of performing such mitigation efforts, and on the role that international and national aid and civil society organizations can play in that regard.

1. Advocate for and support the development of a balanced holistic policy for managing the Syrian de facto refugee crisis that is rooted in a rights perspective and not mere security concerns. Such policy needs to be the result of a national level consultative process, which is inclusive of both humanitarian and political voices, and is discussed away from the eyes and ears of the media.

2. Support the role of municipalities in resolving conflicts at the local level and providing unbiased support to Syrian de facto refugees. This could include training to some key municipal officials on conflict mitigation, and providing opportunities for networking and cooperation with other municipalities in the same region.

3. Strengthen mechanisms and processes that encourage reporting by Syrian de facto refugees of harassment and injustice. Voices that denounce acts of violence against Syrians need to be encouraged and amplified at both the local and national level, as should incidents where Lebanese individuals or groups have successfully defended and protected Syrian de facto refugees.

4. Provide opportunities for track-two dialogue involving political, social, religious, and civil society leaders as opposed to what is called "track-three", or people-to-people dialogue, among relatively moderate figures from different sides of the Lebanese political divide, in addition to representatives of the Syrian refugee population. ${ }^{40}$ This would strengthen networks that are essential for future conflict mitigation efforts, and improve the impact of their reconciliatory efforts. This could include local public figures that have already taken reconciliatory initiatives like the Sunni Mufti of Baalbeck and Hermel, and some family members of killed or abducted soldiers.

5. Support improved accountability and transparency systems within humanitarian organizations, through existing frameworks like those of the Humanitarian Accountability Partnership and the Do No Harm Approach. Also encourage improved coordination among NGOs on measures adapted to combat fraud locally, and ways of ensuring proper reference checks on incoming staff.

\footnotetext{
40 For information on tracks of diplomacy please see http://glossary.usip.org/resource/tracks-diplomacy [last accessed November 17th 2014].
} 


\section{Case Study}

\section{RELATIONSHIPS BETWEEN THE SYRIAN DE FACTO REFUGEES AND THE LEBANESE HOST COMMUNITY IN BAALBECK/HERMEL ${ }^{41}$}

On September $10^{\text {th }}$, four tents of Bedouin Syrian de facto refugees have been burnt in Al-Jabal, a predominantly Shiite village of the Hermel area. This came only four days after the killing of the Lebanese army soldier Abbas Medlej. Syrian de facto refugees reported receiving a series of threats in the previous couple of days asking them to evacuate the land they are staying on within 48 hours. According to Bassma, Syrian de facto refugee mother of five children aged between 1 and 12 years old who has been in Lebanon for two and a half years, around ten masked men came during the night, shot bullets in the air, and threw the flyers around the tent area. On the night of September $10^{\text {th }}$, the tent in which she lives with her husband and children was burnt along with most of their belongings as they rushed out of it to protect themselves. The inside of the neighboring tent of her brother-inlaw, along with two other tents in the adjacent piece of land, were also burnt. This was done again by armed masked men during the night. Young Lebanese neighbor Maha witnessed the attack on September $10^{\text {th }}$ and tried to interfere. She called upon her brother to come and help, but he was threatened by the masked men who fired warning shots in the air and asked him to leave.

Bassma claimed that tents of other Syrian de facto refugees in different areas in Al-Jabal were attacked on the same night. Bassma said that she was reluctant to complain, but about five days later her husband made contact with the municipality asking for a tent and was promised one. A month later they still had not received one and were staying at the brother-in-law's tent. Previously, international organizations had provided them with a water tank and toilet facilities that are still standing.

The four burnt tents were standing on three adjacent pieces of land, each with a different owner, and the response and protection provided to the Syrian de facto refugees under attack was relative to the living arrangement they had. The Lebanese owners of one piece of land who belonged to a notable family interfered and managed to identify the attackers, allegedly members of another notable local family. They sought apology positing the attack as one that targets them since it was against guests staying in their land, and would be similar to attacking them at home. Syrians living on the third plot of land also worked for the landowners as laborers in various agricultural lands they have, and had close ties with them. Reconciliation and apology as befitting local custom took place between the two families, but without a direct apology to the Syrian families. Neither Bassma's family nor that of her brother-in-law sought protection from the land owner as one of them was just renting the land with minimum interference, while the other one was not taking any rent in exchange for families staying on his land. In fact, most of the Syrians on the latter piece of land moved after that incident into a piece of land that belongs to an employer of theirs to ensure his protection.

Although the flyers were signed by the "Hermel tribes", a quick check with tribal leaders confirms that they had nothing to do with it and that their name was falsely used. Based on the little we could gather, and as in other similar incidents we heard of, the attackers appear

\footnotetext{
41 Names of individuals and villages (although all in this case study are in the Baalbeck/Hermel area) are fictitious to ensure the protection of the research participants, with the exception of locations within the city of Baalbeck where the size of the city makes the issue of anonymity less pertinent.
} 
to be just "a group of irate young men", as Bassma described them, who have no political or family backing. If there is a will to identify and reprimand them by local authorities or figures, their abusive action is almost always restrained. What is evident though is two trends contributing to the continued vulnerability. For one, most Syrians being attacked almost always refrain from reporting out of either fear or a feeling that the local host community sanctions such attacks. In addition, the local communities sustain a practice of silence, and minimize the frequency and intensity of such incidents, often with attempts to portray the relationship with Syrian de facto refugees in a positive light and presenting these incidents as exceptional and rare cases. Attacks are paralleled with rumors circulating in the same period through telephone messages about a possible attack by the ISIL or the NF, or claims that the army has deployed a large number of members in the area. While these rumors are easy to refute given that they cite known media sources as their reference, they appear to spread widely with no efforts of rumor control.

Residents in houses and other rented spaces within residential areas in close by villages and towns reported similar attacks. In Al-Sahl, one family reported young men coming around their houses at night, throwing stones at the windows or screaming insulting remarks. In Baalbeck, one family reported young men claiming to be security personnel though given their young age, the family is certain they are not - doing mock searches of the house in the middle of the night. One of the young men filmed the incident on his cell phone in what appears to be an attempt to show off to others later on. While one family in Al-Sahl indicated that such incidents stopped after being reported to the municipalities, many did not report.

Such assaults have a different impact when targeting young women. In one incident, also in the mixed village of Al-Sahl in the Hermel area, a young women, Rana, reported being repeatedly harassed by a young Lebanese guy and his friends and brothers after breaking her engagement with him. As a result, she and her parents were physically and verbally abused several times, and the young man, who falsely claimed to belong to a powerful local party, threatened that there will be further harm to the family if she was not to marry him. Rana reports him saying to her father "Who do you think you are? You are in our land now, and I could get you kicked out in no time". Sixteen-year-old Rana described feeling guilty that all the family is going through is her fault, and how she considered getting back with her ex-fiancé to save her family the trouble. After a few such assaults, the family reported what is happening to a distant family relative who actually belonged to that local political party, and the young men refrained from any further attacks.

Young Syrian men also seem to be particularly vulnerable because they are accused of being politically active with Islamist groups or because they are obliged to move at night due to work conditions. In Al-Sahl for example, a curfew preventing Syrians from moving in the village at night and another decision prohibiting them from going around on motorcycles after seven are enforced. While the municipality and its local police are responsible for that, young men reported that they were routinely questioned by security agents, and also harassed by young men in cars with dark windows who claim to be doing local security checks. Several fights have erupted between the Lebanese and the Syrian youths, and often the youths of the "Eastern neighborhood" are to blame. Youths in the "Eastern neighborhood" were described by Lebanese and Syrians alike as "troublemakers", but now with the presence of Syrian de facto refugees, the frequency of the fights they were involved in has increased. During one of these fights, a Syrian young man was injured and had to be hospitalized. The municipality and local notables intervened and paid for the hospitalization costs but no disciplinary action was taken against any of the individuals 
concerned. In Baalbeck, young men reported being subjected to physical attacks and theft, particularly at night when they return from work at the local restaurants. While their employers try to provide protection, and at times provide transportation when possible, they have discussed cases when they were too scared to go back home and opted for spending the night at their work place instead. In recounting these incidents, these young men not only expressed great anxiety but also despair, and wondered if it was not better for them to be back in Syria and join the fighting. ${ }^{42}$

Members of Al-Sahl's municipality do confirm that such actions take place, noting that they are trying to interfere and provide protection when contacted, and are encouraging reporting. For their part, they complained of increased crime perpetuated by Syrian de facto refugees, including pick pocketing and theft. Municipal officials also reported one case of sexual assault on a female resident, after which the perpetrator was expelled out of the village, which eventually led his family to move with him too. That said, as mentioned above, the attacks by Lebanese vigilante groups against the Syrian families do not seem to be considered as 'crimes' and the disciplinary action taken against the perpetrators is not equitable to the action taken against Syrian de facto refugees. In addition, they claimed that attacks by the Lebanese are primarily due to a feeling that Syrian men are competing with the Lebanese for jobs. They reported that because of the influx of Syrian workers, skilled workers and small business owners, especially in construction, are practically without work, and have requested that the municipality enforce a minimum unified pay for both Lebanese and Syrians - knowing that Syrian de facto refugees are accepting lower wages that are not possible for a Lebanese to accept. That said, we have not heard of any concrete examples of conflict emanating from such competition. Members of the municipality indicated that they also received a green light from the governor to search houses of Syrian de facto refugees and do any needed security checks, as well as employadditional local police if needed (see figure 8).

Beyond direct physical and verbal attacks, and the hesitation to report, some Syrian families' vulnerability means that they are easily cheated out of their agreed pay or exploited by local employers. Also in Al-Sahl, one Syrian family spoke of their 17 year old son killed by a speeding car. According to the family, the driver did not have a license, and a claim to the police was made that it was actually his brother driving. The family was given a compensation of seven million LBP (4,650 USD), which was claimed to be the appropriate amount according to local custom, and the family of the perpetrator gave their condolences a few times. While the family feels it had been unjustly treated and was not provided adequate protection and sees the amount they were given was too little, they accepted to reconcile to avoid trouble. While they were advised by some Lebanese acquaintances to take the case to court, particularly since insurance companies might be obliged to pay a larger amount, they are reluctant and feel that the process will not bring them justice either.

In brief, the relationship between the Syrian de facto refugees and the Lebanese host communities needs to be understood within the context of power imbalance. Young Syrian men and women, and families of Syrian de facto refugees appear to be the easiest targets for attacks and blame in the current tense security situation, as well as for exploitation through local level patronage networks. Silence of Lebanese authorities and political groups in response to such attacks and exploitation appears as an endorsement of their perpetrators. Vocal condemnations at the local level appear to be of great conflict mitigation value and need to be supported.

\footnotetext{
42 It is worth noting that these young men presented a variety of political and ethnic groups, including Kurds as well as both regime and free Syrian army supporters.
} 


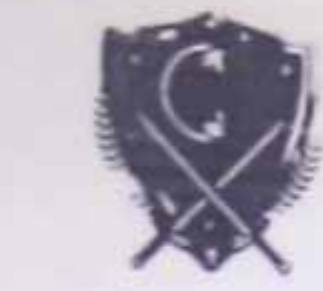

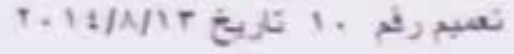

$$
\begin{aligned}
& \text { أئ كانة البلديات والمخفارين في الفرى }
\end{aligned}
$$

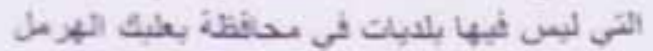

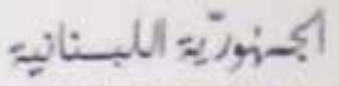

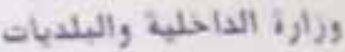

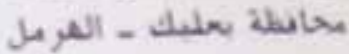

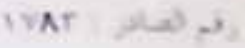

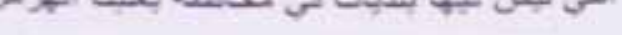

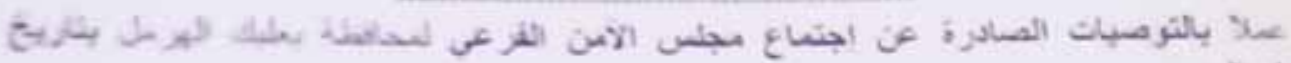

$$
\begin{aligned}
& .+12 / \mathrm{M} / \mathrm{T}
\end{aligned}
$$

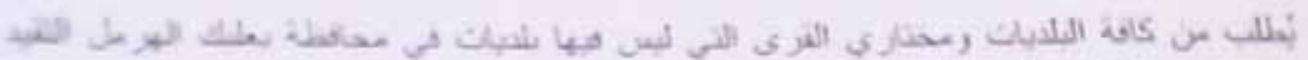

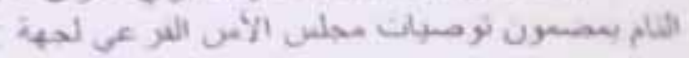

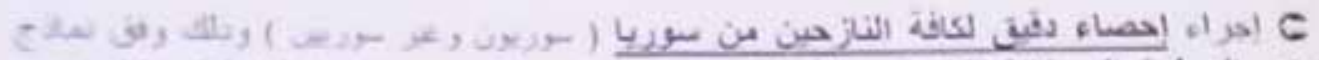

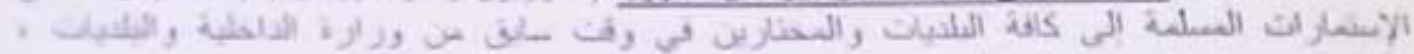

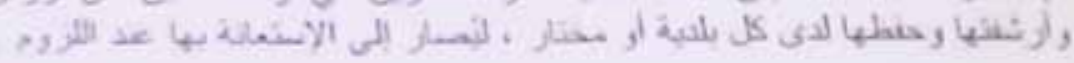

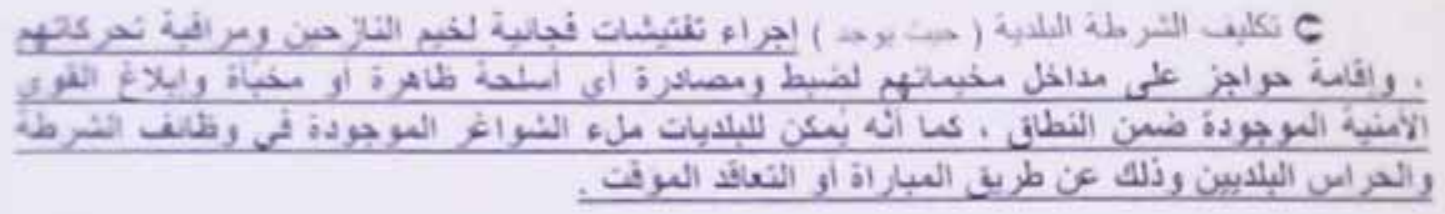

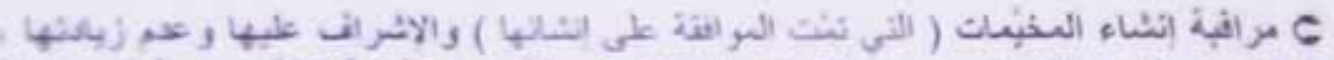


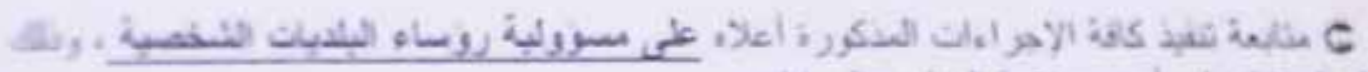

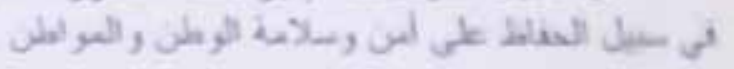

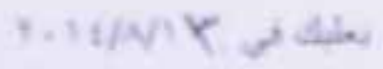

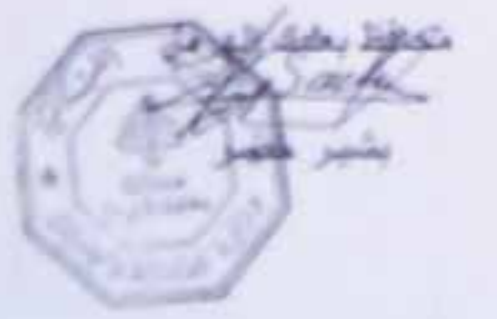

\section{FIGURE 8:}

Memorandum from the governor of Baalbeck /Hermel to municipalities in his area on security measures to be taken regarding Syrian de facto refugees (dated 13 August 2014). Source: author's personal archive. 
